This is an open access article under the CC BY-NC-ND license

Issue IV, 22 November 2021

e-ISSN 2707-9481

Institute of Metallurgy and Ore Beneficiation, Satbayev University, Almaty, Kazakhstan

\author{
Gladyshev Sergey Vladilenovich \\ Institute of Metallurgy and Ore Beneficiation, \\ Satbayev University Almaty, Kazakhstan \\ Email: s.gladyshev@satbayev.university \\ ORCID ID: 0000-0002-4939-7323
}

\author{
Azlan M.N. \\ Sultan Idris Education University, Perak, Malaysia \\ Email: azlanmn@fsmt.upsi.edu.my \\ ORCID ID: 0000-0002-2792-4145
}

\title{
Production of non-ferrous metal concentrate in the processing of pyrite slags
}

\begin{abstract}
The method of preliminary chemical activation of mineral raw materials was used in the conducted studies for the complex processing of pyritic slags. The influence of preliminary chemical activation of kaolinite clays of Alexeevsky deposit in the solution of sodium hydrogen carbonate on the separation of kaolinite and quartz fractions was studied. The temperature of 150 ${ }^{\circ} \mathrm{C}$, the duration of 120 minutes, and the concentration of sodium bicarbonate solution of $120 \mathrm{~g} / \mathrm{dm}^{3}$ should be considered the optimum mode of activation. As a result of activation, the phase composition of the kaolinite fraction changed: the percentage of kaolinite fraction decreased; new phases of muscovite and sodium aluminosilicate appeared; the amount of quartz increased.

Keywords: pyritic slags, chemical activation, leaching, phase composition, non-ferrous metals, neutralization, concentrate.
\end{abstract}

Cite this article as: Gladyshev S.V.; Azlan M.N. (2021). Production of non-ferrous metal concentrate in the processing of pyrite slags. Challenges of Science. Issue IV, pp. 76-81. https://doi.org/10.31643/2021.11

\section{Introduction}

One of the ways to produce sulfuric acid is roasting pyrite concentrate to produce sulfurous gas [12]. The resulting pyrite slag is stored, which creates a real threat of pollution of the water and air environment, while at the same time they are a valuable source of ferrous, non-ferrous, and noble metals, not used to date due to the lack of economically viable technologies. In this regard, the development of effective, integrated technology intended to process pyrite slag is relevant.

Pyritic pellets are equal to good iron ores in terms of iron content (50-60\%), but their use for smelting pig iron is prevented by the presence of base metals and sulfur in them. Therefore, the technological scheme of processing should provide a sufficiently complete extraction of non-ferrous metals and obtain a product suitable for blast-furnace smelting.

The main method of processing pyritic slags introduced in some countries is chlorination roasting followed by leaching of nonferrous metal compounds $[2,6,12,13]$. However, the high-energy consumption and the need to leach excessively large volumes is a disadvantage of the method, which reduces its practical significance.

Based on the available information [3, 7-10], the predominant direction of research is hydrometallurgical methods, which require improvement for complete utilization with the extraction of useful components - non-ferrous, precious metals, and iron.

The method of preliminary chemical activation of mineral raw materials was used in the conducted studies for the complex processing of pyritic slags. It promotes disintegration and phase changes $[1,4,5$, 11]. The method consists of thermal treatment with a solution of sodium bicarbonate. Due to the conditions of chemical activation, the hard-to-recover phases are modified and the mineral structure is disclosed by separating the non-metallic materials. 
The optimal conditions for the preliminary chemical activation corresponding to the peculiarities of the mineral structure of pyritic slags were determined. The positive effect of activation is confirmed by the results of the leaching of non-ferrous metals from pyritic slags in sulfuric acid solution.

\section{Methods}

X-ray fluorescence analysis was performed with a Venus 200 wave dispersion spectrometer (PANalyical B.V., The Netherlands).

Chemical analysis of the samples was performed on an optical emission spectrometer with inductively coupled plasma Optima 2000 DV (USA, Perkin Elmer).

Semi-quantitative X-ray phase analysis was performed on a D8 Advance diffractometer (BRUKER) using copper $\mathrm{Cu}-\mathrm{K} \alpha$ radiation at an accelerating voltage of $36 \mathrm{kV}$, current $25 \mathrm{~mA}$.

Chemical activation of pyritic slags was carried out in a solution containing $40-120 \mathrm{~g} / \mathrm{dm}^{3} \mathrm{NaHCO}_{3}$ at S:L=2-10.0 and a temperature of $90-230^{\circ}$ using a thermostatic unit with 6 autoclaves rotating through the head, with a working volume of $250 \mathrm{~cm}^{3}$. The duration of activation ranged from 30 to 300 minutes. The maximum content of sodium hydrogen carbonate $120 \mathrm{~g} / \mathrm{dm}^{3}$ in the solution is chosen to take into account its solubility limit

\section{Results, discussion}

A representative sample of pyrite slag from the sulfuric acid production of the Tselinnyy Mining and Chemical Combine of Kazakhstan was used in this work.

According to the results of sieve analysis, it was found that in the class $+2.5 \mathrm{~mm}$ content of useful components - noble, nonferrous metals, and iron is much lower (Table 1).

Table 1. Chemical composition of classes of pyritic slags

\begin{tabular}{|c|c|c|c|c|c|c|}
\hline \multirow[t]{2}{*}{ Content, \% } & \multicolumn{6}{|c|}{ Size class, $\mathrm{mm}$} \\
\hline & +2.5 & $-2.5+1.0$ & $-1.0+0.25$ & $-0.25+0.1$ & $-0.1+0.056$ & -0.056 \\
\hline $\mathrm{Na}_{2} \mathrm{O}$ & 2.44 & 1.43 & 1.19 & 0.959 & 0.75 & 0.71 \\
\hline $\mathrm{MgO}$ & 3.29 & 0.65 & 0.67 & 0.483 & 0.41 & 0.39 \\
\hline $\mathrm{Al}_{2} \mathrm{O}_{3}$ & 10.96 & 6.92 & 6.37 & 4.163 & 3.11 & 3.03 \\
\hline $\mathrm{SiO}_{2}$ & 39.73 & 27.09 & 25.18 & 16.13 & 11.89 & 11.44 \\
\hline $\mathrm{P}_{2} \mathrm{O}_{5}$ & 0.26 & 1.26 & 1.1 & 0.956 & 0.84 & 0.82 \\
\hline $\mathrm{SO}_{3}$ & 0.51 & 7.33 & 8.1 & 7.725 & 6.35 & 6.1 \\
\hline $\mathrm{CaO}$ & 9.72 & 2.84 & 2.62 & 1.949 & 1.41 & 1.2 \\
\hline $\mathrm{TiO}_{2}$ & 1.26 & 0.42 & 0.37 & 0.25 & 0.178 & 0.16 \\
\hline $\mathrm{Fe}_{2} \mathrm{O}_{3}$ & 7.63 & 41.63 & 45.63 & 60.94 & 70.187 & 71.16 \\
\hline $\mathrm{CuO}$ & 0.02 & 0.2 & 0.22 & 0.26 & 0.261 & 0.28 \\
\hline $\mathrm{ZnO}$ & 0.04 & 0.4 & 0.4 & 0.61 & 0.604 & 0.66 \\
\hline $\mathrm{As}_{2} \mathrm{O}_{3}$ & 0.06 & 0.19 & 0.25 & 0.26 & 0.258 & 0.26 \\
\hline $\mathrm{SeO}_{2}$ & 0.003 & 0.51 & 1.01 & 0.57 & 0.23 & 0.19 \\
\hline $\mathrm{BaO}$ & 0.186 & 2.07 & 2.33 & 2.81 & 2.866 & 3.01 \\
\hline $\mathrm{HgO}$ & - & 0.09 & 0.19 & 0.14 & 0.055 & 0.04 \\
\hline $\mathrm{PbO}$ & 0.005 & 0.15 & 0.17 & 0.2 & 0.185 & 0.21 \\
\hline No & 22.266 & 6.29 & 3.61 & 1.237 & 0.146 & 0.08 \\
\hline $\mathrm{Au}, \mathrm{g} / \mathrm{t}$ & 0.021 & 1.58 & 2.68 & 2.69 & 2.24 & 2.88 \\
\hline $\mathrm{Ag}, \mathrm{g} / \mathrm{t}$ & 0.1 & 11.2 & 16.2 & 19.3 & 21.4 & 22.3 \\
\hline Output, \% & 31.0 & 6.2 & 5.5 & 20.8 & 34.3 & 2.2 \\
\hline
\end{tabular}


Magnetic separation determined that the $+2.5 \mathrm{~mm}$ class is the non-magnetic fraction and the -2.5 $\mathrm{mm}+0$ class is the strongly magnetic fraction; it was separated at a magnetic field strength of $200-400$ oersted.

Chemical composition of the magnetic fraction of pyritic slags of size class - $2.5 \mathrm{~mm}+0 \mathrm{wt} . \%: \mathrm{Na}_{2} \mathrm{O}$ 1.4; $\mathrm{MgO}$ 0.74; $\mathrm{Al}_{2} \mathrm{O}_{3}$ 5.69; $\mathrm{SiO}_{2} 23.22 ; \mathrm{P}_{2} \mathrm{O}_{5}$ 1.1; $\mathrm{SO}_{3}$ 6.24; $\mathrm{Cl} 0.01 ; \mathrm{K}_{2} \mathrm{O} 0.44 ; \mathrm{CaO} 2.52 ; \mathrm{TiO}_{2} 0.32 ; \mathrm{Fe}_{2} \mathrm{O}_{3}$ 52.84; $\mathrm{CuO}$ 0.25; $\mathrm{ZnO}$ 0.53; $\mathrm{As}_{2} \mathrm{O}_{3}$ 0.24; $\mathrm{SeO}_{2}$ 0.3; $\mathrm{BaO}$ 2.4; $\mathrm{HgO} 0.08 ; \mathrm{PbO} 0.16$; p.p. 1.82; precious metal content, g/t: Au 2,69; Ag 19,3.

The phase composition of the magnetic fraction of pyritic slags is represented, wt. \%: magemite 24.1, hematite 18.1, quartz 17.2, albite 10.2, trisodium phosphate zinc oxide hydrate 9.5, sodium aluminosilicate 6.7 , barium ferrite 4.7 , nitrozarosite 4.2 , sodium thiorphosphate 2.8 and dolomite 2.5 (Figure 1).

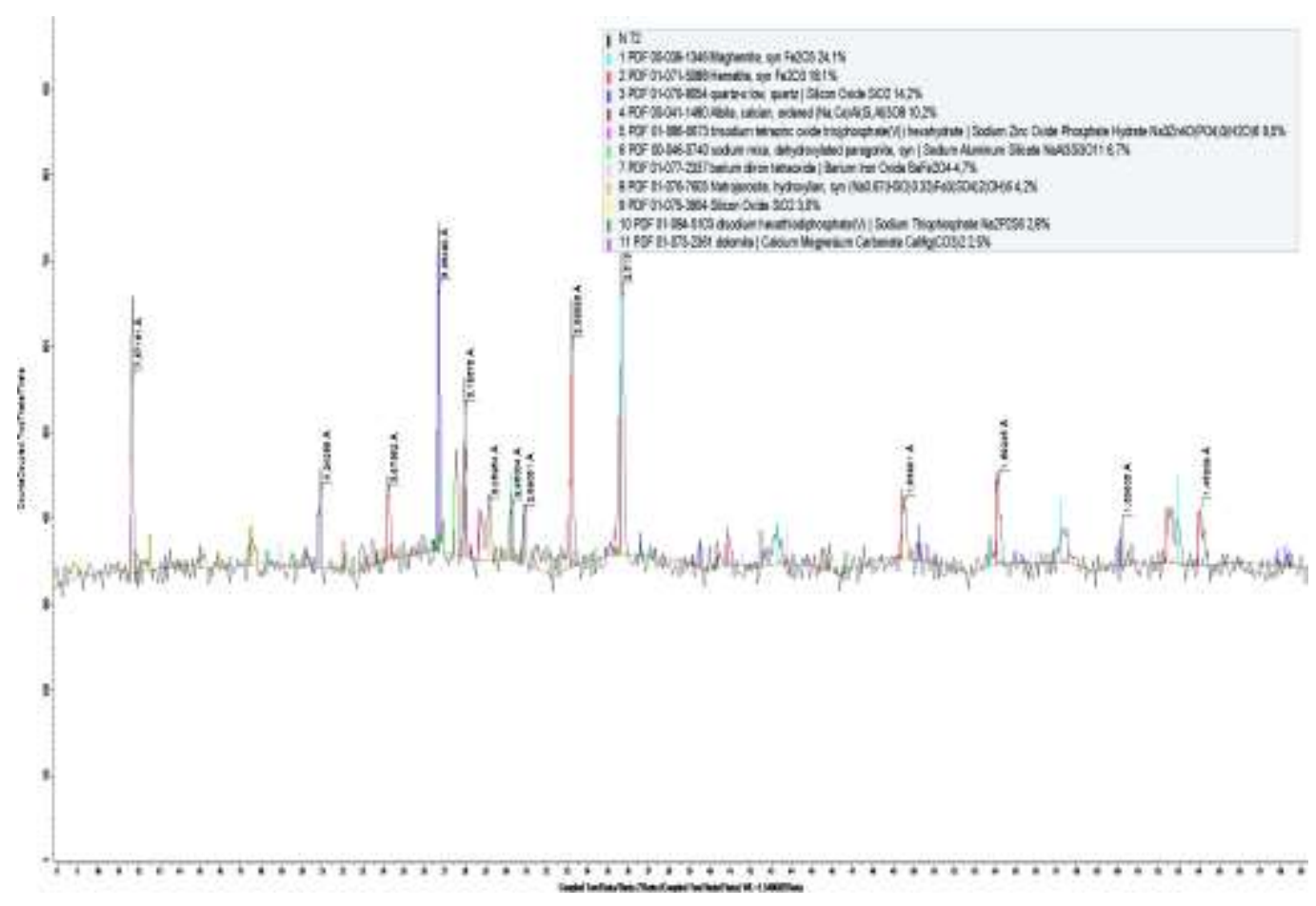

Figure 1. X-ray phase analysis of pyrite slag after chemical activation under optimal conditions

Chemical composition of the magnetic fraction of pyritic slags of size class -- $+2.5 \mathrm{Mm}$ wt.\%: $\mathrm{Na}_{2} \mathrm{O}$ 2.44; $\mathrm{MgO} 29 ; \mathrm{Al}_{2} \mathrm{O}_{3}$ 10.96; $\mathrm{SiO}_{2}$ 39.73; $\mathrm{P}_{2} \mathrm{O}_{5}$ 0.26; $\mathrm{SO}_{3} 0.51 ; \mathrm{Cl} 0.01 ; \mathrm{K}_{2} \mathrm{O} 0.8 ; \mathrm{CaO} 2.72 ; \mathrm{TiO}_{2} 1.26 ; \mathrm{Fe}_{2} \mathrm{O}_{3}$ 7.63; $\mathrm{CuO}$ 0.02; $\mathrm{ZnO}$ 0.04; $\mathrm{As}_{2} \mathrm{O}_{3}$ 0.06; $\mathrm{SeO}_{2}$ 0.003; $\mathrm{BaO}$ 0.186; $\mathrm{HgO} 0.08 ; \mathrm{PbO} 0.005 ;$ p.p. 23.076; noble metal content, g/t: Au 0,021; Ag 0,1.

The phase composition of the non-magnetic fraction of pyritic slags is represented, wt. \%: magemite 2.1; hematite 1.4; quartz 29.9; albite 18.2; dolomite 18.2; calcite 17.3; clinochlore 7.7; muscovite 3.5 and gibbsite 1.4 .

The poor fraction of size $+2.5 \mathrm{~mm}$, the amount of which is more than $30 \%$, was not used in further studies.

To determine the main technological parameters of the preliminary chemical activation, the pellets of class $-2.5 \mathrm{~mm}+0$ were crushed in a ball mill to a coarseness of $-0.056 \mathrm{~mm}$.

The dependence of the chemical activation of pyritic slags in sodium bicarbonate solution on temperature, duration, $\mathrm{S}: \mathrm{L}$ ratio, and $\mathrm{NaHCO}_{3}$ concentration was investigated. It has been determined that the optimum conditions of chemical activation are temperature $120^{\circ} \mathrm{C}$, duration $30-60 \mathrm{~min}$, the $\mathrm{S}: \mathrm{L}$ ratio $=$ $4: 1$, and the concentration of $\mathrm{NaHCO}_{3}$ solution $60 \mathrm{~g} / \mathrm{dm}^{3}$ at which the maximum changes in the phase and chemical composition are obtained.

Chemical composition of pyritic slags after activation under optimal conditions, weight \%: $\mathrm{Na}_{2} \mathrm{O}$ 1.59; $\mathrm{MgO}$ 0.73; $\mathrm{Al}_{2} \mathrm{O}_{3}$ 5.63; $\mathrm{SiO}_{2} 22.3 ; \mathrm{P}_{2} \mathrm{O}_{5}$ 0.59; $\mathrm{SO}_{3} 3.45 ; \mathrm{Cl} 0.01 ; \mathrm{K}_{2} \mathrm{O} 0.43 ; \mathrm{CaO}$ 2.64; $\mathrm{TiO}_{2} 0.31 ; \mathrm{Fe}_{2} \mathrm{O}_{3}$ 51.89; $\mathrm{CuO}$ 0.24; $\mathrm{ZnO} 0.52 ; \mathrm{As}_{2} \mathrm{O}_{3}$ 0.16; $\mathrm{SeO}_{2}$ 0.25; $\mathrm{BaO}$ 2.32; $\mathrm{HgO} 0.09 ; \mathrm{PbO} 0.16 ;$ p.p 6.69. 
Analysis of the chemical composition showed that after activation the content of $\mathrm{P}_{2} \mathrm{O}_{5}, \mathrm{SO}_{3}$, and $\mathrm{As}_{2} \mathrm{O}_{3}$ in pyrite slag decreased by $46.36 \%, 44.31 \%$, and $33.3 \%$ respectively.

The phase composition of pyritic slags after chemical activation under optimal conditions is represented by wt\%: maghemite, 28.4; hematite, 21.8; quartz, 14.7; albite, 8.7; sodium aluminosilicate, 6.0; barium ferrite, 6.2; natrojarosite, 4.3; sodium thiophosphate, 5.7; magnesium aluminosilicate, 2.5 and calcium silicate, 1.7. (Figure 2).

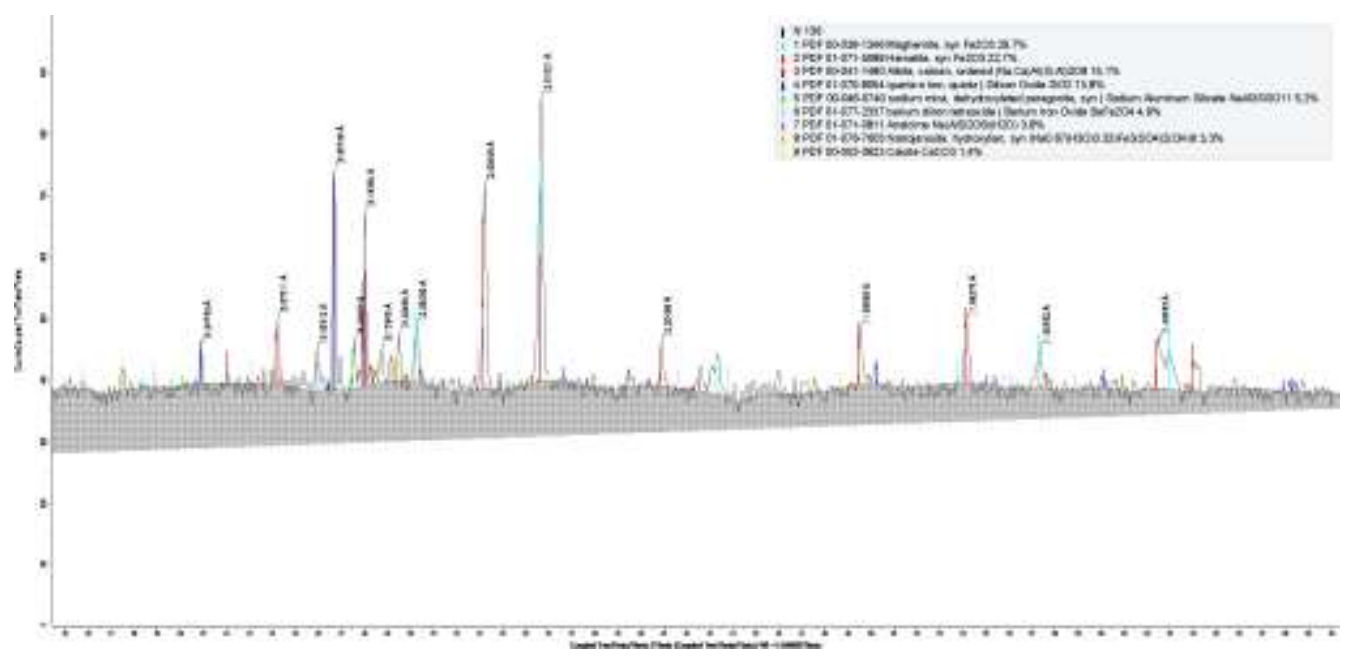

Figure $2 \mathrm{X}$-ray phase analysis of pyritic slag after chemical activation under optimal conditions

As a result of chemical activation of pyritic slags in optimal conditions, the phases of zinc phosphate trinatrium hydrate oxide $\mathrm{Na}_{3} \mathrm{Zn}_{4} \mathrm{O}\left(\mathrm{PO}_{4}\right)_{3}\left(\mathrm{H}_{2} \mathrm{O}\right)_{6}$ and dolomite $\mathrm{CaMg}\left(\mathrm{CO}_{3}\right)_{2}$ disappeared; the amount of sodium thiophosphate phase $\mathrm{Na}_{2} \mathrm{P}_{2} \mathrm{~S}_{6}$ increased from $2.8 \%$ to $5.7 \%$; the amount of albite phase $\mathrm{Na}\left(\mathrm{AlSi}_{3} \mathrm{O}_{8}\right)$ decreased from $10.2 \%$ to $8.7 \%$ and that of natrojarosite $\left(\mathrm{Na}_{0.67}\left(\mathrm{H}_{3} \mathrm{O}\right)_{0.33}\right) \mathrm{Fe}_{3}\left(\mathrm{SO}_{4}\right) 2(\mathrm{OH})_{6}$ $\left(\mathrm{Na}_{0.67}\left(\mathrm{H}_{3} \mathrm{O}\right)_{0.33}\right) \mathrm{Fe}_{3}\left(\mathrm{SO}_{4}\right)_{2}(\mathrm{OH})_{6} 4.2 \%$ to $3.4 \%$; the magnesium aluminosilicate phase $\left(\mathrm{MgAl}_{2} \mathrm{Si}_{3} \mathrm{O}_{10}\right)_{0.6}$, calcium silicate $\mathrm{CaSiO}_{3}$ appeared.

Changes in the phase composition of pyritic slags as a result of chemical activation can be associated with the course of reactions of the interaction of sodium hydrogen carbonate with trisodium phosphate zinc oxide hydrate and natrojarosite with the formation of sodium thiophosphate and an increase in the content of iron-bearing phases, and also with dolomite with the formation of calcium silicate and magnesium aluminosilicate.

Studies were carried out to determine the effect of the chemical activation of pyritic slags on the extraction of non-ferrous metals and iron during leaching in sulfuric acid solutions.

Leaching of pyritic slags after preliminary chemical activation was carried out in $\mathrm{H}_{2} \mathrm{SO}_{4}$ solutions containing $5-20 \%$ at a temperature of $60^{\circ} \mathrm{C}$ and a duration of 30 minutes.

The results of the leaching of pyritic slags in sulfuric acid solutions are shown in Figure 3.

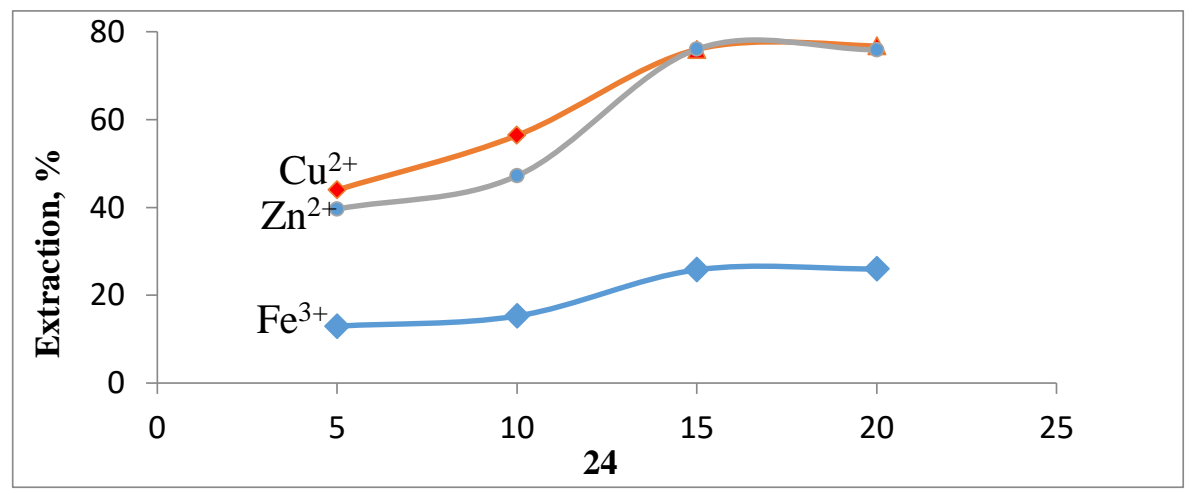

Figure 3. Dependence of non-ferrous metal and iron extraction from pyritic slags after activation in solution on the concentration of $\mathrm{H}_{2} \mathrm{SO}_{4}$ 
According to the data obtained, it is optimal to use a sulfuric acid solution with a concentration of $15 \% \mathrm{H}_{2} \mathrm{SO}_{4}$ for leaching pyritic slags after chemical activation. Under these conditions, the recovery into sulfuric acid solution was, \%: $\mathrm{Cu}^{2+} 76.8 ; \mathrm{Zn}^{2+} 75.9$, and $\mathrm{Fe}^{3+}$ 26.0.

The sulfuric acid leaching solution was neutralized with potash in several stages to obtain a nonferrous metal concentrate (Table 2)

Table 2. Chemical composition of neutralization precipitation depending on solution $\mathrm{pH}$

\begin{tabular}{cccc}
\hline Content, \% & \multicolumn{3}{c}{$\mathbf{p H}$} \\
\cline { 2 - 4 } & $\mathbf{3 . 7}$ & $\mathbf{5 . 4 6}$ & $\mathbf{9 . 7}$ \\
\hline $\mathrm{K}{ }_{2} \mathrm{O}$ & 0.11 & 0.08 & 13.8 \\
\hline $\mathrm{MgO}$ & - & - & 1.2 \\
\hline $\mathrm{Al}_{2} \mathrm{O}_{3}$ & 0.12 & 3.0 & 7.5 \\
\hline $\mathrm{SiO}_{2}$ & 0.12 & 1.2 & 2.9 \\
\hline $\mathrm{P}_{2} \mathrm{O}_{5}$ & 25.27 & 3.5 & 0.02 \\
\hline $\mathrm{SO}_{3}$ & 8.3 & 11.08 & 15.9 \\
\hline $\mathrm{Fe}_{2} \mathrm{O}_{3}$ & 53.37 & 19.3 & 3.8 \\
\hline $\mathrm{CuO}$ & - & 0.04 & 6.4 \\
\hline $\mathrm{ZnO}$ & - & 0.01 & 12.54 \\
\hline $\mathrm{As}_{2} \mathrm{O}_{3}$ & 3.08 & 0.39 & - \\
\hline $\mathrm{SeO}_{2}$ & 0.1 & 0.01 & - \\
\hline
\end{tabular}

Neutralization to $\mathrm{pH} 3.7$ was performed to precipitate trivalent iron from the solution. Under these conditions, phosphorus, arsenic, and selenium partially precipitated from the solution together with iron.

At $\mathrm{pH}$ 5.46, iron, phosphorus, and arsenic residues were released into the neutralization precipitate from the solution.

Neutralization to $\mathrm{pH} 9.7$ was carried out taking into account the $\mathrm{pH}$ of complete precipitation of zinc and copper. As a result, the non-ferrous metal concentrate was obtained with the content, weight. \%: $\mathrm{CuO} 6.4 ; \mathrm{ZnO} 12.55$. The concentrate yield was $8.5 \%$ of the total amount of neutralization sludge or $1.5 \%$ of the initial mass of pyrite sludge. The yield of neutralization precipitation at $\mathrm{pH} 5.46$ was $2.1 \%$, at $\mathrm{pH} 9.7$ $14.2 \%$.

The obtained results indicate that neutralization for impurity extraction of $\mathrm{Fe}_{2} \mathrm{O}_{3}, \mathrm{P}_{2} \mathrm{O}_{5}$, and $\mathrm{As}_{2} \mathrm{O}_{3}$ and obtaining concentrate of non-ferrous metals should be carried out in two stages to pH 5.46 and 9.7.

\section{Conclusions}

The influence of preliminary chemical activation of kaolinite clays of Alexeevsky deposit in the solution of sodium hydrogen carbonate on the separation of kaolinite and quartz fractions was studied. The temperature of $150{ }^{\circ} \mathrm{C}$, the duration of 120 minutes, and the concentration of sodium bicarbonate solution of $120 \mathrm{~g} / \mathrm{dm}^{3}$ should be considered the optimum mode of activation.

As a result of activation, the phase composition of the kaolinite fraction changed: the percentage of kaolinite fraction decreased; new phases of muscovite and sodium aluminosilicate appeared; the amount of quartz increased.

The main technological scheme of the complex processing of kaolinite ore was developed.

\section{Acknowledgments}

This work was based on grant financing No. AR09259455 and supported by the Committee of Science of the Ministry of Education and Science of the Republic of Kazakhstan. 
Cite this article as: Gladyshev S.V.; Azlan M.N. (2021). Production of non-ferrous metal concentrate in the processing of pyrite slags. Challenges of Science. Issue IV, pp. 76-81. https://doi.org/10.31643/2021.11

\section{References}

[1] Abdulvaliyev R. A., Akhmadieva N. K., Gladyshev S. V., Imangalieva L. M., Manapova A. I. (2018). Restorative melting of modified red sludge. Kompleksnoe Ispol'zovanie Mineral'nogo Syr'a = Complex Use of Mineral Resources. 306 (3) - pp. 15-20. https://doi.org/10.31643/2018/6445.12 (in Russian.)

[2] Bingbing He, Sike Tian, Yan Sun, Chao Yang, Yanlin Zeng, Yanxin Wang, SuxinZhan, Zhenban Pi Extraction of iron oxide concentrate from high-sulfur and low-grade pyrite cinder using an innovative enrichment process. Hydrometallurgy. 2010. Volume 104, Issue 2, - pp. 241-246. https://doi.org/10.1016/j.hydromet.2010.06.009 (in English)

[3] Gilmutdinova R. A., Michurin S. V., Kovtunenko S. V., Elizarieva E. N. On the issue of the use and processing of waste from mining and processing plants of the Southern Urals. Uspekhi sovremennogo naturalizaniya. - 2017. - No. 2. - p. 68-73. https://natural-sciences.ru/ru/article/view?id=36365

[4] Gladyshev S. V., Kenzhaliev B. K., Abdulvaliev R. A., Dyusenova S. B., Imangalieva L. M. Development of technology for obtaining chromite concentrate from sludge tailings of enrichment. Kompleksnoe Ispol'zovanie Mineral'nogo Syr'a = Complex Use of Mineral Resources. 2018. - No. 1. - p. 12-17. https://kims-imio.kz/wp-content/uploads/2018/05/kims2018-1-14-19.pdf (in Russian.)

[5] Kenzhaliev B. K. (2019). Innovative technologies that ensure an increase in the production of non-ferrous, precious, rare and rare-earth metals. Kompleksnoe Ispol'zovanie Mineral'nogo Syr'a = Complex Use of Mineral Resources. No. 3. - pp. 64-75. https://doi/org/10.31643/2019/6445.30 (In English).

[6] J. Kakumazaki, T. Kato, K. Sugawara. Extraction of gold from the ash of burnt sewage sludge by chlorination. SelfPropelled Guns Withstand. Chemistry. eng., 2 (2014), pp. 2297-2300 https://doi.org/10.1021/sc5002484 (in English)

[7] Patent 2623948 RU. Publ. 12. 06.2017. Method of complex processing of pyrite stubs. Litvinenko L. G., Litvinenko V. G., Shchelkonogov M. A., Morozov A. A.

[8] Patent 2397,260 rubles. Publ. 20. 03. 13. Sposb of deep processing of pyrite stubs. Mukhamedshin I. Kh., Bashlykova T. V., Fadina I. B., Zhivaeva A. B.

[9] Patent 2716440 rubles. Publ. 20. 03. 20. Method of processing pyrite stubs. Kurdyumov G. E., Galeru K. E., Parshin S. N.

[10] Patent 2149706 rubles. Publ. 19. 03. 2013. A method for processing pyrite stubs. Bakov A. A., Arzhannikov G. I.

[11] Patent 32333 KZ. Method of preparation of aluminosilicate raw materials before leaching. Abdulvaliyev R. A., Gladyshev S. V., V. Pozmogov.A., L Imangalieva.M; publ. 31.08.2017. Byul. No. 16

[12] Chernyshev A. K., Levin B. V., Tugolukov A.V. Sulfuric acid Vol. 1: properties, production, application. - M.: INFOKHIM, 2014. - 654 p. (in Russian)

[13] Yu. Zheng, Z. Liu. Production of monodisperse micaceous iron oxide pigment from pyrite stubs. Powder Technology., 207 (1-3) (2011), pp. 335-342, https: / / doi/org/ 10.1016/j. powtec. 2010. 11. 015 (in English) 